\title{
Modern principles and problems of degradation of cultivated ameliorated soils
}

\author{
Mikhail Bandurin ${ }^{1}$, Inna Bandurina $^{1}$ and Alexander Bandurin ${ }^{2}$ \\ ${ }^{1}$ Kuban State Agrarian University named after I.T. Trubilin, 13, Kalinina st., Krasnodar, 350044, Russia \\ ${ }^{2}$ Novocherkassk Engineering and Reclamation Institute named after A.K. Kortunov, Don State Agrarian University, 111, Pushkinskaya \\ st., Novocherkassk, 346400, Russia
}

\begin{abstract}
The paper considers modern principles and problems of degradation of cultivated ameliorated soils. The current problem of the use of the planet's land resources is that food and fiber production are annually reduced by soil loss and degradation, primarily as a result of human activities. There are many reasons for this dangerous phenomenon, and they differ in different natural and socio-economic conditions. But the end result is always the same everywhere: either a drop in fertility or the loss of the soil itself. Currently, about 7 million hectares of arable land, i.e. the base of life for 21 million people is irrevocably annually lost in the world as a result of various processes of degradation and alienation, with the current norm of 0.3 hectares per 1 person.
\end{abstract}

\section{Introduction}

The area of the Russian Federation is 1178.5 million hectares, agricultural land occupies 318.2 (27\%), arable land - 119 (10.1\%), hayfields and pastures - 201.5 (17.1\%), perennial plantations - 2.4 million hectares $(0.2 \%)$. The length of the country from west to east is more than 10 thousand $\mathrm{km}$, and from north to south it exceeds 4.5 thousand $\mathrm{km}$. The Asian part of the country accounts for $3 / 4$ territories where the annual sum of active temperatures is less than $1500{ }^{\circ} \mathrm{C}$. In our country, about $70 \%$ of land resources are occupied by land located in cold and arid zones [1].

Arable land accounts for 1 people: in Russia - 0.85, USA - 0.79 ha, Canada - 1.84, France - 0.32, China 0.09 , Japan -0.04 ha, etc. On average, there are 0.3 hectares per person in the world, but some calculations show that, on average, each person needs 0.4 to 0.5 hectares for food production and about 0.1 hectares for dwellings, roads and others at the existing average yield level [2]. There are few reserves for expanding productive land on the planet. According to the International Food Organization, the total area of potentially suitable soils for plowing on the planet is 2.52.7 billion hectares. Now, 1.5 billion hectares are in processing. However, the inclusion of additional land in cultivation will require huge costs.

Soil is a valuable natural resource for mankind. Dokuchaev wrote [3] that Russian chernozem is more expensive than coal, oil, gold. The comparison with gold may be perceived not only in the figurative, but also in the literal sense: in the figurative - as a figurative indicator of the enormous value of soil, in the literal - a person could exist without gold, but not without soil.
This is a special natural formation, possessing a number of properties typical for living and non-living nature, formed as a result of a long transformation of the surface layers of the lithosphere under the joint interdependent interaction of the hydrosphere, atmosphere, living and dead organisms. Soil is the basis of the biosphere. Through plants and animals, it ensures the existence of a biosphere and ecological systems. Therefore, its proper use and careful treatment must be seen as an essential element in the integrated protection of nature [4].

Soil cover is the most important natural formation. Its role in the society is determined by the fact that the soil is a source of food providing $95-97 \%$ of food resources for the world's population. The planet's land resources provide food for more people than is currently available. However, due to the population growth, especially in developing countries, land degradation, pollution, erosion, etc., and as a result of the allocation of land for cities, towns and industrial enterprises, the number of arable land per capita is sharply reduced [5].

The impact of man on the soil is an integral part of the general influence of human society on the Earth's crust and its upper layer, on nature as a whole, which increased especially in the age of the scientific and technological revolution. The soil-man problem is complicated by urbanization, the increasing use of land, its resources for industrial and housing construction, and the growing need for food. The nature of soil changes, soil formation factors such as relief and microclimate change, and new rivers appear, etc. as a result of human interference. The main indicator characterizing the impact of pollutants on the natural environment is the maximum permissible concentration. From the environmental point of view, the maximum permissible

\footnotetext{
* Corresponding author: chepura@mail.ru
} 
concentrations of a particular substance represent the upper boundaries of limiting environmental factors (in particular, chemical compounds), in which their content does not exceed the permissible limits of the human ecological niche.

The main sources of pollution are as follows [6]:

- residential buildings and utility enterprises. Household garbage, food waste, feces, construction garbage, waste of heating systems prevails among the pollutants. Together with feces, disease-causing bacteria, worm eggs and other harmful organisms, which enter the human body through food, often enter the soil [7];

- industrial enterprises. Substances that may have toxic effects on living organisms and their communities are constantly present in solid and liquid industrial wastes [8];

- heat power engineering. In addition to the formation of a mass of slags during hardcoal combustion, the release of soot, unburned particles, sulfur oxides, which eventually end up in the soil, is associated with thermal power engineering;

- agriculture. Fertilizers, poisonous chemicals used in agriculture and forestry to protect plants from pests, diseases and weeds;

- transport. Internal combustion engines actively release nitrogen oxides, lead, hydrocarbons and other substances settling on soil surface or absorbed by plants [9]. Each car emits an average of $1 \mathrm{~kg}$ of aerosolised lead per year into the atmosphere.

\section{Materials and methods}

World irrigation agriculture totals 240 million hectares, which is $16 \%$ of the cultivated area. Irrigated areas in the world may be increased by 2-3 times. The main reserves for the expansion of irrigated land are concentrated in the zones of subboreal and subtropical deserts. More than $50 \%$ of all agricultural products (in monetary terms) are obtained from irrigated land.

Irrigation makes significant changes in the landscape environment. In addition to positive changes and increased soil fertility, it may cause undesirable side effects. Valuable land is lost during flooding and mire formation during the construction of dams and reservoirs. The soils of floodplain terraces happen to be under the water. There is salinization and solonization of land, its compaction. Therefore, the actual yield on irrigated land is significantly lower than the planned one and largely depends on land reclamation condition. One of the results of the increasing consumption of mineral resources by humans was a global change in the ecological and geodynamic safety of the natural environment. It is known that intensive mining led to an increase in the load on the subsoil and, as a result, to the redistribution of the stress-strain state of quite significant volumes of rock mass with adverse consequences for the natural environment.

As of January 1, 2020 the total area of irrigated land in Rostov Region amounted to 234.09 thousand hectares, including basin irrigation -4.017 . The area of irrigated land with closed drainage is 58.8 thousand hectares. Of the available irrigated land, 107.9 thousand hectares require an increase in the technical level and comprehensive reconstruction. The reclamation state of 54.7 thousand hectares of land is extremely unsatisfactory: unacceptable groundwater depth is 33.6 ; salinization - 9.0; unacceptable depth of groundwater and salinization -12.1 thousand hectares.

The reasons for the unsatisfactory state of the irrigated land of the region are associated with the imperfection and aging of irrigation systems, most of which were built 50-70 years ago. The main part of the channels is made in an earth channel, without waterproofing, which contributes to the intensive loss of water for filtration.

A system of measures is used to combat and prevent secondary salinization of soils. This is primarily the construction of deep horizontal drainage $(2.5-3.5 \mathrm{~m}$ or a vertical drainage with a depth of $25-80 \mathrm{~m}$ (where lithological and hydrogeological conditions of the irrigated area allow this).

What are the specific causes of degradation and loss of arable land? First of all, millions of hectares are alienated for the needs of non-agricultural use: the construction of reservoirs, quarries, cities, mines, towns, roads, pipelines, communication lines, airfields. According to data for 2020 provided by the United Nations Organization [10], every year more than 700 thousand hectares of arable land are irretrievably used only for the construction of cities and roads in the world. These losses are probably inevitable to some extent, since a person needs housing and roads, and it is impossible to limit only unsuitable areas for farming, but these losses may be reduced quite significantly [11].

Another cause of soil degradation, also widespread throughout the world, is a large complex of various adverse events in irrigated agriculture, especially secondary salinization, solonization, mire formation. Huge amounts of money are spent on combating these phenomena, especially on the construction of artificial drainage structures. But they will almost double the cost of building the irrigation systems. Therefore, drainage is rarely laid hoping that it may not be necessary, and if it is necessary, it will not be soon. This leads to the rise of groundwater, mire formation, salinization, crop losses, and ultimately to the loss of land and investments.

The depletion of soils and the decline in their fertility due to improper, unbalanced use are also worrying. Nutrients are carried out along with the crop, which nature has accumulated for many hundreds and thousands of years. These losses should be compensated by organic and mineral fertilizers. However, the removal of nutrients exceeds their introduction with fertilizers, and soils do not have time to recover, with intensive agriculture the soil does not rest [12].

Finally, another degradation process is underway soil pollution. This is usually the result of the promiscuous use of industrial chemicals: herbicides, insecticides, other toxic chemicals, excessive application of some fertilizers, poisoning of soil with some heavy metals, sulfuric acid, and other wastes of industrial and mining enterprises. For all these and some other reasons, about 7 million hectares of arable land are lost annually. 
But the biggest damage is caused by soil erosion. It leads to disastrous results at some locations on the planet. Data show that in recent centuries erosion and deflation have destroyed about 2 billion hectares of land [13].

\section{Results and discussion}

As a result of improper anthropogenic activity, the areas of joint water and wind erosion are rapidly expanding. When mapping, it is advisable to allocate areas of preferential and equal distribution of water and wind erosion.

Soil losses are of varying intensity. There is the term "erosion rate", i.e. the marginal intensity of soil degradation that is compensated by soil formation processes. For example, in the United States, the permissible rate of erosion is from 2.25 to 11.5 tons/ha per year [14].

The relationship between agricultural production and erosion processes is reflected in the following: without taking into account natural conditions agriculture creates the basis for increasing wind and water erosion; frequent and severe destruction of the soil cover, in turn, causes death and damage to plants, reduces soil productivity, which leads to the destabilization of agricultural production. In this regard, it is crucial to maintain the agricultural system taking into account the potential danger of erosion processes. Permanent sources of atmospheric pollution are known: industry, transport, active volcanoes.

The multilateral adverse impact on the natural environment leads to an irreversible process desertification of land. Desertification is defined as negative changes in soil, vegetation and water regime, which occur under the influence of anthropogenic activities and reduce the productivity of ecosystems, increase soil compliance to destruction by wind or water.

Severe destruction of soils by wind and water erosion caused by improper land use was also noted during the years of development of virgin and fallow lands (19571962) in a number of areas: Northern Kazakhstan, Volga Region and the Caucasus [15].

The increase in the area of cereals and grains was largely caused by plowing of land with a high risk of deflation and erosion, a reduction in crops of perennial grasses, which led to the activation of soil destructive processes.

The analysis of organizational and economic activities revealed the paramount importance of correct selection of proportions of leading industries in the structure of agricultural production for soil protection. The unresolved contradiction between grain production and animal husbandry, as well as imbalances in the structure of crops, is among the main obstacles to the introduction of a set of soil protection measures.

The methods of cropping may be the main means of approaching soils in an erosion-hazardous state. Longterm observations of the state of the soil surface layer during dumping showed that at any cloddiness of the soil upper layer before the snow cover, in most cases during the winter and spring periods, the surface layer of soil is sprayed to a critical level at which it is possible to move soil particles.

Today, Rostov Region is facing a real problem of the development of irrigated agriculture, which directly affects the production of agriculture, which, in turn, depends on the socio-economic situation in the country.

One of the main competitive advantages of Rostov Region is land resources and climatic conditions, which contribute to the dynamic development of agro-industrial complexes [16].

The basis of the arable land of the region is chernozem and chestnut soils. Most of the territory of the region is located in an arid zone, and there is a need for artificial irrigation to obtain high sustainable crops.

Unstable agriculture in Rostov Region is bound to the disappearance of many types of irrigation systems. At present, liman irrigation, sprinkler irrigation, as well as such as Azovskaya, Bagaevskaya, NizhneManychskaya and others are used on the territory of Rostov Region.

To improve the situation it is necessary to restore the previous types of irrigation, the use of waste-free and advanced technologies. It is necessary to introduce facilities for the complete processing of raw materials at enterprises, engineering infrastructure, a highly developed social sphere for employees of agricultural complexes.

An important task of irrigation is also to improve the technical level of the reconstructed and newly built irrigation systems, ensuring the sustainability of production, environmental safety of agro-landscapes, and the conservation of the most important natural resources - land, water and energy.

For example, let us consider the observed trends indicating that due to the presence of fertile land and favorable climatic conditions the territory of Rostov Region may and should become the object of the development of extensive agriculture. In other words, it shall be provided with all the required resources for prospective irrigation [17].

To achieve this, it is necessary to attract investments of large agricultural producers on irrigated land, as well as socio-economic investments for proper functioning of promising irrigation.

The analysis makes it possible to note that land reclamation is a significant agricultural sector and can be used to achieve good results in the development of irrigation.

The prospects for the development of irrigation in Rostov Region are quite high, since the administration of Rostov Region and the government of the Russian Federation takes active measures to improve it [18].

The main directions of land protection are as follows:

- protection of land from water and wind erosion, salts, sub-wind erosion, flooding, mire formation, secondary salinization, drying, compaction, pollution by production waste, and other destruction processes [19];

- reclamation of disturbed lands, improvement of their fertility and other beneficial properties;

- removal and preservation of fertile soil to be used for land reclamation or to increase the fertility of unproductive land. 
The advantages of a soil-protective, plowless agricultural system are that the transition from moldboard plowing to plowless cultivation reduces soil losses 2-4 times, and the introduction of paraploughing on slopes steeper than 10 reduces soil losses 18-23 times. Besides, plowless tillage prevents the appearance of dust storms, cleans the soil from weeds, reduces the pesticide load, slows down nitrification processes in the soil, and reduces the content of free nitrates in agricultural products [20].

The main directions of protection and rational use of mineral resources include the reduction of their losses during extraction, enrichment and processing, improvement of technology and extraction of minerals, integrated use on the basis of development and wide implementation of resource-saving technological processes, creation of low-waste and waste-free industries and complexes.

To protect soils during irrigation from alkalization, natrium salinization, solonization and compactness (where these processes threaten), it is necessary to periodically introduce small doses of chemical ameliorants (gypsum, mineral acids) into the soil or with irrigation water, use physiologically acidic nitric acids (ammonium sulfate, ammonium nitrate, ammonium sulfate nitrate, ammophos, diammophos) and calciumcontaining (ordinary and double superphosphate) fertilizers, introduce perennial legumes into crop rotation. In order to prevent compactness, an irrigation regime is also necessary to prevent waterlogging and drying of soils.

The restoration of natrium salinization soils requires the simultaneous use of deep drainage, high doses of chemical ameliorants (20-50 t/ha of sulfuric acid, gypsum), leaching, large norms of organic, including green manure, and physiologically acidic nitrogenous fertilizers.

In the case of irrigation with water with increased mineralization, preventive irrigation against drainage is required to protect soils from secondary salinization.

In recent years, dangerous exogenous processes have intensified in the Don Valley below the Tsimlyansk hydroelectric complex, which is facilitated by both natural and man-made factors. The most dangerous processes are landslides and coastal erosions.

Comprehensive studies of the natural and technical system of the Lower Don site have been carried out. As a result, data were obtained on the modern state of the river section, causes and factors affecting the formation of landslides and the intensity of erosion of the banks of the Don River, as well as information on the presence and state of coastal protective structures near settlements. The development of landslides was noted in the area of the Mariinskaya village, near the Vedernikov homestead, on the site of the Kanygin homestead Razdorskaya village - Pukhlyakovsky homestead Melikhovskaya village, as well as within the cities of Aksay and Rostov-on-Don. Dangerous stream-bank erosion is observed on the site from the alignment of the Tsimlyansk hydroelectric complex to the city of Aksay.

The following factors contribute to the intensification of landslide processes:
- development of landslide slopes with main buildings and structures, construction of roads that slow down the flow of rain and meltwater, create dynamic loads;

- watering of slopes.

The intensity of coastal erosion is affected by the following factors:

- geomorphological features of the banks (concave sections of the banks are subject to erosion; high erosion intensity near sandy coasts and coasts with sandy layers, small - near clay coasts);

- value of passing water flow rates (at high flow rates the channel processes are more intense than at small ones);

- hydrodynamic effects from passing vessels;

- shortage of sediments in the channel flow in the lower sides of the pressure hydraulic units;

- degree of coast forest coverage;

- dredging operations.

The following are used to protect the shores from erosion:

- bank protection structures;

- stone stream deflectors (thus increasing the intensity of erosion of opposite river banks);

- artificial flushing and filling of beaches and sand spits along eroded shores.

In order to protect socio-economic objects and reduce the intensity of dangerous exogenous processes in the coastal zone of the Don River, it is necessary to ensure the following:

- complex protection of built-up river banks from erosion, removal of new construction facilities outside the flood zone by design flood;

- reduction of watering of landslides, lowering of groundwater level;

- prohibition on placing heavy structures of main buildings and structures on landslides;

- arrangement of landslides;

- reduction of hydrodynamic impacts on the shores from passing ships, removal of a fairway from built-up shores, artificial washing of sandy protective beaches;

- conservation and plantation of forests in the coastal zone of eroded shores;

- use of stone stream deflectors to protect the banks from erosion taking into account their possible effect on the intensity of erosion of the opposite river bank.

The obtained results may be used to solve a wide variety of tasks:

- creation of various monitoring systems, decision support systems;

- development of layout schemes for economic, residential and recreational facilities;

- planning and development of measures to control the harmful effects of water;

- design of coast protection facilities;

- use of water resources, etc.

\section{Conclusion}

Strong development of erosion is manifested on soils which surface is exposed and contains a large number of 
particles easily transported by wind or water. Such conditions are created as a result of the destruction of vegetation, uncontrolled grazing, and use of agricultural equipment that does not meet local natural conditions. Consequently, the reasons for soil erosion are mainly not natural factors, but rather the nature of human production activities, which do not take into account possible soil degradation. The main method of combating soil contamination with heavy metals is the removal of the surface contaminated layer of soil. Then this place is covered with at least $30 \mathrm{~cm}$ of the new layer of uncontaminated soil. Quite often, shrubs and trees are planted along motorways to clean the soil. Liming belongs to agrotechnical methods of control. Liming reduces lead levels in crops grown in contaminated areas.

The Russian Federation closely monitors soil pollution in agricultural areas in the immediate surroundings of cities and industrial facilities, as well as at the background level.

All kinds of pesticides are controlled in agricultural soils: hexachlorocyclohexane, ethylmercurchloride, polychloropropylene, metaphos, ziram, sevin, heptachlor, and others. The analysis of contaminants entering the ground surface is important to understand soil pollution processes, especially as a result of atmospheric transport. Atmospheric pollution is monitored for this purpose. In the conditions of our country it is important to monitor the pollution of the snow cover, since pollutants come to the surface with the melting of snow.

\section{References}

1. V. N. Shchedrin, S. M. Vasilev, A. V. Kolganov, L. N. Medvedeva, A. A. Kupriyanov, Espacios, 39(12) (2018)

2. V. I. Olgarenko, G. V. Olgarenko, I. V. Olgarenko, International Multidisciplinary Scientific GeoConference SGEM, 18(3.1), 3-9 (2018)

3. I. F. Yurchenko, Journal of Physics: Conference Series, 1015, 042063 (2018)

4. L. V. Kireicheva, O. A. Zakharova, Eurasian Soil Science, 35(9), 990-995 (2002)

5. I. F. Yurchenko, International Journal of Advanced and Applied Sciences, 4(2), 72-77 (2017)
6. N. F. Ryzhko, F. K. Abdrazakov, S. N. Ryzhko, S. V. Botov, Journal of Fundamental and Applied Sciences, 10(6S), 1482-1497 (2018)

7. I. P. Kruzhilin, M. A. Ganiev, V. V. Melikhov, K. A. Rodin, N. N. Dubenok, A. S. Ovchinnikov, S. D. Fomin, N. M. Abdou, Journal of Engineering and Applied Sciences, 12(24), 7118-7123 (2017)

8. D. V. Kozlov, A. N. Nasonov, I. M. Zhogin, I. V. Tsvetkov, Water Resources, 44(2), 259-266 (2017)

9. M. A. Bandurin, I. F. Yurchenko, I. P. Bandurina, 2019 International Multi-Conference on Industrial Engineering and Modern Technologies, FarEastCon 2019, 8933970 (2019)

10. I. F. Yurchenko, Journal of Theoretical and Applied Information Technology, 96(5), 1253-1265 (2018)

11. M. A. Bandurin, V. A. Volosukhin, A. V. Mikheev, Y. V. Volosukhin, I. P. Bandurina, IOP Conference Series: Materials Science and Engineering, 327(2), 022010 (2018)

12. G. V. Degtyarev, K. A. Belokur, I. V. Sokolova, Materials Science Forum, 931, 141-147 (2018)

13. I. F. Yurchenko, Bulletin of Russian Agricultural Science, 1, 13-17 (2017)

14. O. Degtyareva, G. Degtyarev, I. Togo, V. Terleev, A. Nikonorov, Yu. Volkova, Procedia Engineering, 165, 1619-1628 (2016)

15. O. G. Degtyareva, G. V. Degtyarev, N. L. Lavrov, D. U. Aliev, Magazine of Civil Engineering, 82(6), 32-48 (2018)

16. M. A. Bandurin, V. V. Vanzha, V. A. Volosukhin, A. V. Mikheev, Y. V. Volosukhin, I. P. Bandurina, Journal of Physics: Conference Series, 1118(1), 012005 (2018)

17. B. P. Chesnokov, O. V. Naumova, V. A. Strelnikov, F. K. Abdrazakov, B. A. Tronin, International Journal of Applied Engineering Research, 11, 21402144 (2016)

18. V. I. Olgarenko, G. V. Olgarenko, I. V. Olgarenko, Melioration and water management, 6, 8-11 (2013)

19. P. P. Gaydzhurov, S. F. Al-Dzhabobi, M. A. AlKhadzh, News of Higher Educational Institutions of North Caucasus region, 2, 73-78 (2017)

20. N. Fen, D. B. Kozlov, I. S. Rumyantsev, Power Technology and Engineering, 49(5), 337-344 (2016) 